\title{
Juri Joensuu
}

\section{Fiktiiviset reseptit ja mahdottomat ateriat kirjallisen komiikan lajina: matoherkkua, muovikeittoa, potentiaalista salaattia.}

Ellei ole valinnut dieetikseen valoravintoa, ruoka ja juoma ovat ihmisen kehollisuuden välttämättömiä ylläpitäjiä. Samalla ne sisältävät paljon myös kulttuurisia ja henkisiä ulottuvuuksia. Ehkäpä tämä kaksihahmotteisuus on tehnyt ravinnosta, juomista ja niiden nauttimisesta erityisesti koomisen ja humoristisen kirjallisuuden perusaiheita. Ruuat, juomat ja niiden valmistamisen tavat kantavat historiallisia, taloudellisia, poliittisia, eettisiä, esteettisiä ja kielellisiä merkityksiä.

Tarkastelen artikkelissa sitä, miten kaunokirjallisuudessa on hyödynnetty ruuan ja juoman valmistamisen ohjeita sekä ruokien luettelointia osana kirjallista komiikkaa. Ruokalajien tai -ohjeiden keksiminen tuntuu olevan kirjailijoita puhutellut mielikuvituksen käyttämisen tapa, johon liittyy kosolti koomisia mahdollisuuksia. En ole tässä yhteydessä niinkään kiinnostunut kirjailijoiden kirjoittamista tai kirjallisiin teksteihin upotetuista "oikeista" resepteistä, vaan rajaan aineistoni erikoiseen kirjallisen kulinarismin lajiin: resepteihin, ruokalistoihin tai annoksiin, joiden valmistaminen tai nauttiminen olisi todellisessa elämässä mahdotonta tai ei-toivottavaa. Olen siis kiinnostunut fiktiivisistä, fantastisista, fantisoiduista ja mielikuvituksellisista aterioista. Esimerkeissäni ruokiin liittyviä tekstilajeja käytetään kirjallisiin, taiteellisiin ja humoristisiin tarkoituksiin. Näitä tarkoituksia - kirjallisten annosten poetiikkaa - selvittelen.

Pohdin reseptiä lajin, kerronnan ja poetiikan näkökulmasta, analysoin parodisia ja satiirisia reseptejä ja ruokalistoja sekä fantastisia (utopistisia) ruokia. Esittelen myös tapauksia, joissa ruokatematiikka yhdistyy kokeelliseen kirjoittamiseen, menetelmiin kirjoittamisen resepteinä. Lähestymistapani yhdistää kirjallisuuden ja kirjoittamisen tutkimusta antropologisen, kulttuurisen ja semioottisen ruokatutkimuksen ${ }^{1}$ näkökulmiin. Kirjallisten reseptien, kuten muunkin ruoka- ja juomatematiikan tutkimus, kytkeytyy kysymykseen kirjallisuuden ja elämän suhteista. Komiikkaan liittyen mukana kulkee sellaisia aiheita kuin maku, halu, affektit, transgressio, ruumiillisuus ja yhteiskunnallisuus. Suurimmalta osaltaan uudemmasta kotimaisesta kirjallisuudesta koostuvan aineistoni tarjoilema huumori vaihtelee reseptin muodolla tai annosten luetteloinnilla leikittelystä ja ainesosilla ilottelusta yhteiskunnalliseen satiiriin, moni- (joskus myös vasten-) mielisistä yhdistelmistä älyllisiin paradokseihin. Usein kirjalliset reseptit kytkevät inhon ja huvittavuuden kaksinapaiseen pariin yleisempiä, sosiaalisia tai yhteiskunnallisia teemoja. 
Vaikka kyseessä on ensinäkemältä kapea kirjallisen huumorin kaistale, esimerkkejä löytyy silti sekä kotimaisesta että ulkomaisesta proosasta ja runoudesta. Kirjallisuuden suuressa ravintolasalissa näyttäisi olevan tilausta erilaisille mielikuvituksellisille tarjoiluille.

Yksi kirjallisten tai mahdottomien aterioiden kantakokeista on ranskalainen renessanssikirjailija François Rabelais (1494-1553), jonka neljässä karnevalistisessa romaanissa syöminen ja juominen ovat keskeinen osa kansankulttuurista lähtevää, kaikkea virallista ja vakavaa pilkkaavaa groteskia realismia. Karnevalistisen aterian mittasuhteet ovat yleensä paisuteltuja: esimerkiksi Pantagruelin neljäs kirja (2014) sisältää 12-sivuisen luettelon hillittömästä (tietysti paastonajan) ateriasta, jonka aikana syödään "alati jatkuvan juomatarjoilun siivittämänä" (Rabelais 2014, 268) muiden lihaisien herkkujen ohella "harmaahaikaroita, harmaahaikaranpoikasia, trappeja, trapinpoikasia, niittykirvisiä, helmikanoja, kurmitsoja" jne. (Rabelais 2014, 260). Rabelais piikittelee uskonnollista kaksinaismoralismia fantastisella aterialla, jonka eksessiivisyyttä allekkainen luettelointi korostaa.

Suomalaisen kirjallisuuden perustava fantisoitu ateria on Jukolan Juhanin vastakertomus, jonka hän esittää Hiidenkivellä Aapon legendalle "jalosta uskonsoturista, joka istui [- - ] vankina Impivaaran luolissa” ja tuli toimeen vain uskollaan, raikkaalla vedellä ja hedelmillä, joita ihmeenomaisesti ilmestyi hurskaalle vangille. Hiidenkivellä kärsittävän nälän lisäksi Juhanin juurevaa persoonallisuutta ärsyttää Aapon tarinan henkistynyt ja ylevä rigorismi:

Niin, niin, kerrotaanpa tarinaa vielä toisellakin lailla. Kerrotaan, että viisi mustaa sonninsarvea ilmestyi äkisti miehelle luolan seinään. Koska hän nyt aukaisi ensimmäisen sarven, niin roiskahtipa siitä suhisten ulos parasta, heleätä vapriikin paloviinaa ruokaryypyksi, joka kylläkin veti ryppyyn miehen huulet. Toisesta sarvesta taasen kiskoi hän kyynärittäin ulos monipoimullista, rasvaista ja lämmintä sianmakkaraa. Mutta kolmannesta pinnisteli kankeana kaarena ulos parasta uutispuuroa, ja neljännestä piimää puuronkastiksi, piimää sakeata kuin terva. Ja koska hän nyt oli täyttänyt maarunsa kuin puutiainen, niin aukaisi hän vallan vikkelästi viidennen sarven ja siitä lappasi hän ulos pikanellia, parasta tanskan punttirullaa, joka paisui pojan poskessa kuin imevä iilimato. Tarvitsiko enään parempaa trahtamenttia joutilas mies? (Kivi 2012, 206.)

Juhanin vastavetoon kuuluu, että kuvailtu ateria on rasvaisen ravinteikas, ja maallista nautintoa täydentävät aperitiivi (viina) ja digestiivi (purutupakka). Tällaisessa ruokien ja juomien luetteloinnissa voi havaita keksimisen ja kuvittelemisen nautiskelevan eetoksen, jossa nälkäisessä kehossa asuva ihmismieli askartelee puhtaasti positiivisen elämänalueen parissa. Surumielisemmän sävyn tämä fantasia saa, jos ottaa huomioon 1800-luvun lopun nälkäkatastrofien historiallisen taustan, jolloin kukaan Alexis Stenvallin aikalaisista tuskin sai Juhanin kuvittelemaa täydellistä ateriaa. 


\section{Resepti: lajin, kerronnan ja poetiikan kysymyksiä}

Resepti on helposti tunnistettava tekstilaji. Yleensä resepti sisältää erillisinä luettelevan osuuden (raaka-aineiden listaus, tarkat mittayksiköt) ja suorasanaisen ohjeistuksen:

DRY MARTINI

$6 \mathrm{cl}$ gin

1 cl valkoinen vermutti (kuiva)

1 oliivi

1. Kaada ainesosat jääpaloilla täytettyyn sekoituslasiin. 2. Hämmennä.

3. Siivilöi jäähdytettyyn cocktaillasiin. 4. Koristele oliivilla.

Toisaalta mittayksiköt on mahdollista myös upottaa tekstiin:

Täytettyä lampaanlapaa. - Irroita lapaluu varovasti, jos ei sitä ole tehty jo lihakaupassa, täytä reikä murekkeella, joka on valmistettu 1 kupillisesta leipäjauhoja, 2 ruokalusikallisesta voita, 1 ruokalusikallisesta hakattua persiljaa, 12 oisterista, 1 sitruunan mehusta, 1 teelusikallisesta suolaa, 1/4 teelusikallisesta pippuria ja 1 munasta. Ompele reikä kiinni. [jne.]" (Keittokirja. Suomalainen sosialistinen kustannusyhtiö, Fitchburg 1915.)

Yleensä ruokaresepti on kirjoitettu joko imperatiivissa ("lisää jauhot") tai passiivissa ("lisätään jauhot"). Reseptin sukulaisia ovat taulukot, ohjeet ja luettelot. Ainesosien selostukset, ruokalajien tai aterioiden kuvaukset, ruokalistat ja muut tekstit, joissa luetellaan, järjestellään tai ryhmitellään ruokia tai juomia, ovat lähellä reseptiä. Sekä ruokalista (menyy tai muu) että resepti esittävät luetteloimalla potentiaalisen - joko valmistettavissa tai valittavissa olevan - annoksen. Laajempi keittokirjallisuuden laji voidaan jaotella esimerkiksi 1) keittokirjoihin eli reseptikokoelmiin, 2) dietetiikkatai ravitsemusoppaisiin sekä 3) gastronomiseen kirjallisuuteen (kuten Brillat-Savarin 1988), joka keskittyy korkeatasoiseen ruuanvalmistukseen ja ruokailuun kulttuurisina ilmiöinä (Knuuttila 2010, 14-16). Keittokirjallisuuden historiasta löytyy myös erilaisia lajihybridejä ja "sisäisfiktioita", kuten kulinaarisia jekkuja tai reseptiparodioita (Adamson 1995) tai antiikin ja keskiajan reseptejä "joita ei käytännössä koskaan ole pystytty toteuttamaan, koska niissä on kuvitteellisia ainesosia” (Hämeen-Anttila \& Rossi 2015, 161). Reseptin funktio voi olla kulinaarisen lisäksi myös lääketieteellinen tai maaginen (Goody 1995, 137). Antiikista uudelle ajalle ulottunut esoteerinen traditio piti sisällään alkemiaan ja okkulttiseen tietoon liittyviä juomien, aineiden ja mikstuuroiden ohjeita.

Reseptin suhde kerrontaan tai kertomukseen on monihahmotteinen. Yleisessä mielessä reseptit toki ovat "kuin pieniä kertomuksia, joilla on omanlaisensa juoni ja kertomuksellinen strategia” (Knuuttila 2010, 119). Reseptiä ja kertomusta yhdistävät lähettäjä ja vastaanottaja, konteksti sekä välitettävä, verbaalinen sisältö (Leonardi 1989, 340). Resepti myös periaatteessa täyttää kertovuuden minimivaatimuksen, esittää tapahtumia ajallisessa järjestyksessä. Joskus resepteissä on tunnistettavissa "ääni”, kertoja, joka 
tekee oletuksia, arvostelmia tai käyttää kielikuvia. Siitä huolimatta resepti (sellaisenaan) ei David Hermanin $(1997,1047)$ mukaan kuitenkaan ole kertova teksti. Resepti ei kuvaa sitä, miten jotain tapahtui, vaan on pikemminkin "karkea kaavio mahdollisille tapahtumille". Yksinkertaistaen: fiktiivisen kertomuksen tapahtumat ovat fiktiivisiä, kun taas resepti tähtää todellisiin tapahtumiin. Käskymuotoinen ohje on kuitenkin lähellä sellaista toisen persoonan kerrontaa, jota sitä tyypitellyt Brian Richardson kutsuu "subjunktiiviseksi", imperatiiviseksi, konditionaaliseksi - tai "reseptimuodoksi"2 (Richardson 1991, 319). Samassa yhteydessä Richardson kutsuu ruokareseptejä "pseudo-narratiiviseksi” muodoksi. ${ }^{3}$ Vaikka uskomme narratologeja siinä, että reseptit ovat ei- tai pseudonarratiiveja, on mahdollista löytää monenlaisia reseptin ja kertovan proosan risteytyksiä.

Proosafiktion ja reseptin mahdolliset yhdistelmät voi alustavasti hahmotella seuraavasti.

(1) Kertojan tai henkilön kerronta ruuan valmistuksesta ja/tai aineosista on niin tarkkaa, että tekstiä voisi käyttää reseptinä, kuten Veikko Huovisen novellissa "Stalinin syntymäpäivän vietto keskitysleirillä" (1986), jossa neuvostovangit saavat yllättäen utopistisen hienon juhla-aterian. ${ }^{4}$

(2) Resepti on upotettu kerrontaan: kerronta sisältää graafisesti - kappalejaolla ja sisennyksillä - erotettuja reseptejä. Olga Tokarzukin (s. 1962) romaanissa Päivän talo, yön talo reseptit niveltyvät tarinaan: esimerkiksi pikkupojan surmanneen aterian resepti ("Valkokärpässientä smetanassa") toimii emotionaalisena, taaksepäin kerronnan ajassa viittaavana elementtinä, ei potentiaalisena futuurina (Tokarzuk 2004, 172-173). Tämä resepti ei ole koominen.

(3) Kerronta on upotettu reseptiin: reseptiä laajennetaan kuvailevilla ja kertovilla elementeillä, kuten Harry Mathewsin (1930-2017) novellissa "Maalaisresepti Keski-Ranskasta", jossa reseptin kertoja ujuttaa mukaan muun muassa pitkähkön kansantarinan. Vladimir Nabokovin munankeitto-ohjeessa (1999, 33) on kirjallista tyylittelyä, joka ei olisi munien valmistamisen kannalta välttämätöntä: ”Jos muna [--] halkeaa vedessä [- - ja ulos alkaa pursuta valkoista ainetta paksuna vaahtona, niin kuin aikoinaan meedion suusta, nosta se pois kattilasta ja viskaa menemään.”

Runoudessa on lainattu reseptin muotoa tai kaavaa, jolloin sen tunnistettava muoto täytetään poeettisella kielellä (ks. esim. Lähde \& al. 2004). Visuaalisesti ja graafisesti resepti muistuttaakin säemuotoista runoa. Koska reseptit sisältävät ainesosien luettelointia, luettelorunoissa on usein reseptimäinen vivahde. Sekä luetteloon että reseptiin on helppo siirtää yllättäviä sisältöjä. Esimerkiksi Väinö Kirstinän "Yksi salaatti” (kokoelmassa Luonnollinen tanssi, 1965) assosioituu paitsi nimensä myös joidenkin ruokamaisten ainestensa ("yksi muna / yksi valkoinen kivi / [- - ] yksi myrkyllinen pyrstö") vuoksi metaforisen yhteiskunnallisen salaatin "ohjeeksi".

Fiktiivinen resepti jää tavallaan kahden maailman välille. Se on muotonsa ja lajihistoriansa nojalla ikään kuin toimintaohje lukijalle, se ehdottaa annosta, projisoi sen lukijalle, merkitsee (merkitsijän lailla) mahdollista ateriaa. Osa kirjallisten reseptien 
komiikasta perustunee henkilökohtaisen maun ja fyysisen kokemustodellisuutemme aktivoimiseen: ruokaohje virittää lukijassa ruokamielikuvia ja kehollisia ruokamuistoja, vaikka annos olisikin mahdoton toteuttaa. Kuten komiikassa usein, tässäkin tapauksessa tarkoituksella asetettu paradoksi, osien inkongruenssi, saa aikaan koomisen vaikutuksen. Seuraavassa esittelen ohjeita ja aterioita, joista yhtäkään ei voi, tai ei ole suositeltavaa, toteuttaa kotikeittiöissä.

\section{Kylmiä alkupaloja: satiirikon keittiössä}

Yksi reseptin kirjallinen käyttötapa on satiiri, ruokaohjeeseen sisältyvä yhteiskunnan epäkohtiin tai ihmisen viheliäisyyksiin kohdistuva kritiikki. Satiirisissa ruokaohjeissa on selvästi havaittavissa kirjallisten reseptien kaksoisrooli: tunnistettavaa muotoa käytetään johonkin muuhun tarkoitukseen kuin ruokaohjeen välittämiseen. Juha Ruusuvuoren (s. 1957) "Lama-ajan keittokirja" pilaili Pahkasika-lehdessä 4/1991 ajankohtaisesti ruokien statusarvoilla.

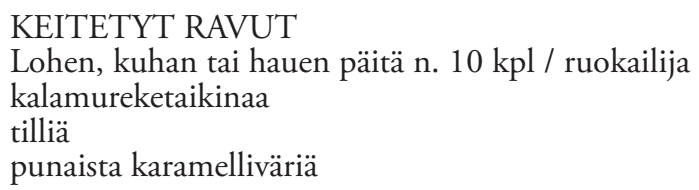

Kalanpäät keitetään puhtaiksi vedessä, johon on lisätty suolaa, tilliä ja karamelliväri. Kalamurekemössö ruiskutetaan paineella päiden onteloihin, joista sitä on mukava imeskellä. Kestien jälkeen päät kerätään talteen. (Ruusuvuori 1991, 57.)

Rapujuhliin edelleen liittyvät yläluokkaiset tai muuten hienostuneet mielikuvat toimivat reseptissä harhaisen sosiaalisen nousun välineenä. Äyriäisiin nähden ravintona arvottomampi frutti di mare, kalanpäät, valmistetaan (naamioidaan) vaivalloisesti muistuttamaan rapua, jotta sen yhtä vaivalloisen syömisen ympärille voitaisiin edelleen, lamasta huolimatta, kerääntyä rituaalisesti ja vaalia sosiaalista arvokkuutta. Satiirinen resepti vihjaa, että rapukestien hienous on alun perinkin itsepetosta.

Myös Veikko Huovinen (1927-2009) kokeili varhaistuotannossaan yhteiskunnallisella satiirilla maustettua kulinariaa. "Uusia ruokia" (1959) koostuu kolmesta parodisesta reseptistä, joissa ruuanlaittoon käytetään yhteiskunnallisesti latautuneita mutta ravinnoksi soveltumattomia aineksia, kuten lääkkeitä ja tupakkaa. "Antibiootikon muovikeiton” hilpeän pinnan alla on näkymä dystooppisista vitsauksista.

Antibiootikon muovikeitto

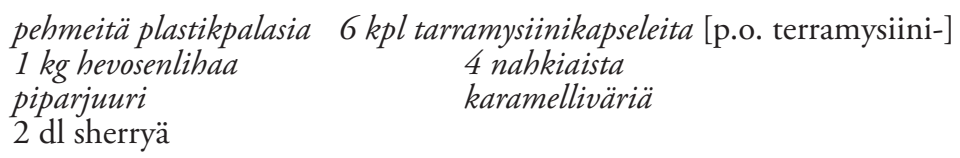


On eduksi, jos plastikpalaset ovat monivärisiä, sillä talvi maassamme on synkkä. Zwickaun muovi ei kelpaa kovuutensa takia. Hevosenlihan annetaan kiehua puoli tuntia piparjuurien kera sherryssä. Muovi ja terramysiini lisätään, samoin vettä. Keitto värjätään karamellivärillä purppuranpunaiseksi. Tunnelman huippu saavutetaan, kun taivaansinisiksi värjätyt nahkiaiset lasketaan uiskentelemaan keittolautasille. Syödään hauskasti somistetussa pöydässä. Juoma Bobadilla y Cia Jerez. (Tarpeen vaatiessa voidaan hevosenlihaan pistellä viikon ajan ennen keiton keittämistä miljoona kansainvälistä yksikköä penisilliiniä.) (Huovinen 2012, 192.)

Keinotekoiset, teolliset partikkelit - kapselit, palaset, lääkeyksiköt ja värit - toistuvat yhdistelmässä, jossa mikään ei soinnu yhteen, juomasuosituskin on espanjalaista brandya. Plastikpalaset ja terramysiinikapselit (tetrasykliineihin kuuluva antibiootti) ovat molemmat teollisen maailman tuotteita, jotka suunniteltiin helpottamaan elämää mutta jotka lähtivät ihmisen hallinnasta. Puoli vuosisataa "Muovikeiton" kirjoittamisen jälkeen "plastikpalaset" muodostavat valtamerien eläimistöä tuhoavia lauttoja ja superbakteerit ovat uhkakuvien mukaan ottamassa niskalenkin meistä antibiootikoista.

Huovisen novellipari "Pystyyn marinoitu nainen" ja "Rasvamaksa" (1973) liittyy satiirisen ihmissyönnin perinteeseen. ${ }^{5}$ Yleensä ihmislihasta valmistettu ruoka herättelee ruokahalun sijaan tuohtumusta, koska se on mahdoton ateria juridisista, eettisistä, ehkä myös kulinaarisista syistä. "Pystyyn marinoitu nainen” sisältää reseptimäisen tarkan ja neutraalin kuvauksen tamperelaisesta "hum. kandista" valmistetusta ateriasta. ${ }^{6}$ Ihmissyönti on ollut ironisen ja satiirisen ruokahuumorin väline vähintään Jonathan Swiftistä (1667-1745) alkaen. Hänen nykylukijaakin hätkähdyttävä klassikkosatiirinsa "Vaatimaton ehdotus" (A Modest Proposal, 1729) ivailee rationaaliselle yhteiskunnalliselle ongelmanratkaisulle ehdottamalla irlantilaisen katolisen köyhälistön jälkikasvun valmistamista ruuaksi, koska lapsi on

mitä herkullisinta, ravitsevinta ja terveellisintä ruokaa niin muhennettuna, paahdettuna kuin keitettynäkin, enkä epäile lainkaan etteikö se kelpaisi yhtä hyvin myös viillokiksi tai höystöksi. [- - etu- tai takaneljänneksestä saa kohtuullisen aterian; mikäli se maustetaan ripauksella pippuria ja suolaa, se on keitettynä oikein maukasta vielä neljäntenäkin päivänä [- - ]. (Swift 1998, 166.)

Huovisen novellissa "Parempi kohtelu keskitysleireille" (1967) satiirin kohteena ovat ihmisen pohjimmaiseen hyvyyteen uskovat optimistit. Sitä jäsentää tuskainen tietoisuus itseään toistavasta historiasta, jossa ihmiskunta ei koskaan pääse eroon sodista, vainoista ja sadismista. Kuten myöhemmässä sisartekstissään ”Stalinin syntymäpäivän vietto keskitysleirillä”, tässäkin on kyse monitasoisesta utopiasta, jossa epäinhimillisiä olosuhteita jäsentää ruoka. Satiirin ytimenä on ironinen toive siitä, että kun keskitysleirejä taas seuraavan kerran perustetaan, voisi niissä vallita inhimillisemmät olot. Kun "Syntymäpäivässä” keskeisellä sijalla ovat tarkat juhla-aterioiden kuvaukset, tässä ruuat on jäsennelty tarkasti suunniteltuihin ruokalistoihin. 
Ruokavalioon olisi kiinnitettävä täysi huomio. Seuraavassa esitetään kaksi viikon ruokalistaa. Näistä vaihtoehto I edustaa ruokavaliota oloissa, joissa elintarviketilanne on normaali. Vaihtoehto II on sovellettavissa äärimmäisen niukoissa säännöstelyoloissa. $\mathrm{L}=$ lounas, $\mathrm{P}=$ päivällinen.

\section{VAIHTOEHTO I}

Ma L. Silakkalaatikko, omena.

P. Vasikkavatkuli, makaroneja. Puolukkakiisseli.

$\mathrm{Ti}$ L. Kesäkeitto, mannapuuro.

P. Paistettua pakastekalaa, perunasose. Rusinasoppa.

$\mathrm{Ke} \quad$ L. Paistetut perunat. Kaakaota korvapuustien kera.

P. Merimiespihvi. Omenahyve. [- - ]

\section{VAIHTOEHTO II}

Ma L. Porkkana-vehnälesevelli. $100 \mathrm{~g}$ sekaleipää.

P. Palvihevoskeitto. Vesipuolukoita.

$\mathrm{Ti} \quad$ L. Ohrapuuro kokojyvistä.

P. Palvihevos-kaalilaatikko.

Ke L. Keitettyjä suolasärkiä. $100 \mathrm{~g}$ perunoita.

P. Ruisleipä mieheen. Kapahaukikeitto.

To L. Kaurasuurimo-maitopulverivelli. Suolasäynettä.

P. Lihapurkki mieheen Oggatsu-Klappatsukorven valtauksen kunniaksi.

Näkkileipää. 10 cl Tähkäviinaa. [- -] (Huovinen 1990, 61.)

Ruokalajien näennäisen neutraali esitys on novellin satiirin syömähammas. Luettelointi paljastaa asetelman mahdottomuuden ja tuo esiin ruokaan kätkeytyviä merkityksiä. H. K. Riikosen tulkinnan mukaan "humoristi yrittää inhimillistää ihmisten säälimättömyyttä kehittämällä lainsäädäntöä tulevia keskitysleirejä silmälläpitäen.” (Kivistö \& Riikonen 2012, 338). Asian voi nähdä myös toisin: teksti näyttää ihmisen säälimättömyyden ironisen inhimillisyyden kautta, pistävän ristiriitaisena kuvaelmana. Keskitysleirille tuodaan kansalaisyhteiskunnasta, työpaikoilta ja kouluruokaloista tutut ruokalajit jälkiruokineen. Yritys humaanisuuteen on kuitenkin käsitteellisesti mahdoton, mihin sen ovela satiiri perustuukin. Miksi yhteiskunta, joka pitää omia kansalaisiaan keskitysleirissä, kokisi tärkeäksi priorisoida heidän viihtyvyyteensä ja laadukkaaseen ravitsemukseensa kivoine jälkiruokineen? Keskitysleiri, jossa saa kaakaota ja korvapuusteja, on häijy paradoksi, jonka voi lukea myös ruokalistasta: "omenahyveeseen" sijoitetusta etiikan käsitteestä, hyveestä.

Ruokasatiiria voi löytää myös yllättävistä paikoista, kuten Antti Salmisen (s. 1983) runollisesta ja rakenteeltaan ensyklopedisesta romaanista Lomonosovin moottori (2014). "Löytyneiden papereiden" seassa on teksti, joka on otsikoitu "Alkemistin keittokirja: hallusinogeneettiset jälkiruoat ja kylmät alkuruoat". "No, mitä me sitten söimme odottaessamme Suuren Työn valmistumista? Kyllä se on syytä kertoa. Toisia kiinnostavat nimenomaan ruokailuun liittyvät yksityiskohdat.” (Salminen 2014, 202.) 
Pitkään pidin eniten kivikeitosta. Siinä vasta eettinen ateria. Koko elämäni olen tuntenut sympatiaa paitsi eläinkuntaa, myös kasvikuntaa kohtaan. Eläinravinnon lisäksi myös kasviravinto on helposti vaihdettavissa kiviruokaan. On vain suosittava suoloja ja sulavia mineraaleja. Esimerkiksi kristalliliuskat, joita Igumeni tuo maan alta, jatkavat mahassa kasvuaan ja ovat siksi täyttä ravintoa. [- - Kivistä saa myös teetä, jota suosittelen hauduttamaan pitkään. [- - ]

Sen sijaan vakaumukselliset lihansyöjämme tavoittelivat valinnallaan Suurta Ketoosia (SK), jonka on määrä seurata kehon puhdistuttua kasviperäisestä törystä. (Salminen 2014, 202.)

Ravinnon valintaan liittyy ainainen problematiikka: myös vegaanisen ihmisen on lopultakin syötävä, nieltävä ja tuhottava jotain fyysisen maailman eläviä (eläneitä) entiteettejä pysyäkseen itse hengissä. Valoravinnon ohella kividieetti näyttäisi olevan ainoa ravintoideologia, joka ei vahingoita faunaa eikä flooraa - joskin vain jälkimmäinen näistä on poeettista ja satiirista fiktiota, toisin kuin voisi luulla. Toisaalta "Suuri Ketoosi” piikittelee ketoosin aiheuttavaa vähähiilihydraattista, usein lihapitoista dieettiä. Satiirin kärki kohdistuu ruokavalioihin autuaiksi tekevinä uskomusjärjestelminä.

\section{Surrealistiset ja abjektiiviset reseptit}

Kun edellä esiteltyjä reseptejä yhdisti satiiri, seuraavien ohjeiden komiikka liikkuu enemmän kulinaarisen provokatiivisuuden alueilla, maustaen tarjoomuksia valikoiduilla abjektioilla - Julia Kristevan termi voimakkaalle inhon kokemukselle jossa koko olemassaolon stabiilius joutuu uhatuksi. Kristevan $(1982,2)$ mukaan ruokaan kohdistuva inho on kenties perustavin ja arkaaisin abjektion muoto. Resepti tai annos, joka yhdistää vieraita, ajattelujärjestelmissämme toisiaan hylkiviä alueita, tuottaa inhoa. ${ }^{7}$ Abjektiota lievempään inhoon voi yhdistyä myös kiehtovuutta ja siihen voi säilyä analyyttisempi etäisyys, reseptin älyllinen havainnointi. ${ }^{8}$ Seuraavissa esimerkeissä toistuvat hätkähdyttävät siirrot sekä ajatuksellisten ristiriitojen huumori houkuttavat tarkastelemaan niitä myös surrealismin näkökulmasta.

Kalevi Seilosen (1937-2011) romaanissa Metsäroisto (1986) kertojana on nimeämätön mies, joka elää jatkuvalla pakomatkalla, vaihdellen asemapaikkaansa metsissä ja kaupungeissa. Kerronta raportoi muisteluita, ohjeita, anekdootteja sekä "metsäroiston" erikoisia näkemyksiä ja teorioita, joissa on hyvin paranoidi sävy. Olennainen tekijä teoksen koomisessa kerronnassa on sen epäluotettavuus: se sekoittaa todellisia sekä keksittyjä tapahtumia, henkilöitä ja sitaatteja nopeiden vaihdosten periaatteella. Teos on myös metafiktio: se leikittelee kerronnan keinoilla, tekijän ja kertojan identiteeteillä sekä viittauksilla oikeisiin ja keksittyihin lähdeteoksiin. Kolmesta liiteosiosta yksi ("Ruokaohjeita") esittelee kahdeksan reseptiä. 


\section{Metsäroiston kalaherkku}

Otetaan vastakalastettuja pikkukaloja, ahvenia, särkiä, pieniä lahnoja tms. Suomustetaan, poistetaan sisälmykset ja evät, huuhdotaan hyvin. Maustetaan suolalla ja valkopippurilla. Syödään raakana tillin kanssa. Koska kaloista voi saada matoja, juodaan pirtua tarpeeksi että madot kuolevat.

\section{Ukin erikoinen}

Kootaan $2 \mathrm{dl}$ isoja muurahaisia ja $1 \mathrm{dl}$ erilaisia syötäviä hyönteisiä, mahdollisimman monia lajeja.* Paistetaan muurahaiset paistinpannussa, lisätään hyönteiset ja annetaan hautua. Maustetaan varovasti suolalla ja timjamilla. Syödään haarukalla lautaselta joko sellaisenaan tai keitetyn riisin kanssa.

*Käsikirjaksi suositellaan Väinö Nykäsen teosta Suomen luonnonvaraiset syötävät hyönteiset.

(Seilonen 1986, 77-78.)

Metsäroiston reseptit liittyvät sivistyksestä luopumiseen ja pakoprojektiin: "jos menee tarpeeksi syvälle metsään ja rupeaa eläimeksi, on syötävä kastematoja ja sammakoita. Minä kerron reseptit niihin.” (Seilonen 1986, 5-6.) Reseptit liikkuvat toteuttamiskelpoisten ja mahdottomien reseptien koomisesti virittyneessä välitilassa. Viittaus Väinö Nykäsen tietokirjaan, jota ei oikeasti ole olemassa, liittyy romaanin jatkuvaan pseudo-lähteiden ja oikeiden lähteiden sekoittamiseen. Edelliset kaksi ohjetta, kuten myös resepti voitaikinalla täytetyille kastemadoille, ovat vahvasti survival-henkisiä, ja ne perustuvat aineisosiin (raaka kala, hyönteiset, madot), jotka luultavasti säväyttivät aikalaisia enemmän kuin nykylukijaa. ${ }^{9}$

Seuraavat kaksi sukusoluihin perustuvaa annosta eroavat jo mainitusta Nabokovin (1999) munienkeitto-ohjeesta, joka on kirjallisesti tyylittelevä mutta käyttökelpoinen. Yhdysvaltalaisen Russell Edsonin (1935-2014) lyhytproosasta, joka "rakentuu surrealistisen ja koomisen, banaalin ja groteskin hyvin tunnistettaville yhdistelmille" (Salmela 2011, 7), löytyy elämänfilosofinen munaresepti.

\section{Munat}

Vatkaa ne ennen kuin ne löytävät nokkansa ja kyntensä.

Erottele keltuaiset valkuaisista. Vatkaa valkuaiset untuvaiseksi vaahdoksi. Vatkaa keltuaiset kärpäslätkällä takahuoneessa.

Sekoita nopeasti keltuaiset valkuaisten kanssa ennen kuin ne unohtavat miten olisi voinut olla...

Erottele keltuaiset valkuaisista. Laita keltuaiset sivuun tekopesään minne yksikään jumala ei kurki. Vatkaa valkuaiset tiheäksi töhnäksi muumioituneella kanan jalalla. Lisää keltuaiset.

Varo itseäsi! Unohda itsesi! Erottele! 
Toista

Toista

Toista...

(Edson 2011, 100.)

Reseptin kertoja käyttää sanavalintoja, jotka eivät herätä ruokahalua ("tiheää töhnää"), kuin olisi tietoinen kaksoisroolistaan reseptin välittäjänä ja runon ironisena "äänenä”. Ohje on loppupäästä avoin: vuorottelu munan osien yhdistämisen ja erottamisen (elämän ja kuoleman) välillä on loputon, prosessi ei pysähdy kumpaankaan. Jo tämä infiniittisyys tekee reseptistä absurdin: reseptinhän tulee tähdätä annoksen valmistumiseen ja sulkeutua siihen. Munat olisivat niihin koodatun tavoitteen mukaisesti tulossa kanoiksi, mutta kokin toiminta pitää niitä syntymisen ja raaka-aineena pysymisen ikuisessa välitilassa.

M. A. Nummisen (s. 1940) "Teen todellinen maku” on juomaresepti, jonka underground-henkinen komiikka ei sovellu alaikäisille. Teksti on muodoltaan ohje teen valmistamiseksi: se jakautuu kuuteen kappaleeseen, jossa ohje toistuu ja kertautuu.

Teen todellinen maku

I Valitaan aito savi- tai porsliinipannu. Mitataan pannuun yksi jälkiruokalusikallinen teenlehtiä kutakin kupillista kohti. Tämän jälkeen kaadetaan kiehuvaa vettä pannuun, ja annetaan teen hautua 3:sta 5:een minuuttia. Nyt tee on valmista tarjottavaksi.

II Tee valmistetaan samoin kuin kohdassa I neuvottiin. Maito kiehautetaan toisessa, erillisessä astiassa, joka voi olla mistä tahansa aineesta valmistettu, esim. emaljista tai ruostumattomasta teräksestä. Kuuma maito kaadetaan kuppiin ensin, sitten vasta tee.

III Tee ja maito valmistetaan kuten kohdissa I ja II neuvottiin. Neilikat kuumennetaan vedessä, jota ei kuitenkaan päästetä kiehahtamaan. Tätä voimakasta "neilikkauutetta" kaadetaan uunissa lämmitettyyn kuppiin. Sen lisäksi lisätään maito ja viimeksi tee.

IV Tee, maito ja "neilikkauute" valmistetaan kohdissa I, II ja II osoitetulla tavalla. Huoneenlämpöistä vodkaa lämmitetään pulloa kuumassa vedessä pitäen. Kuppiin kaadetaan ensin vodka, sitten "neilikkauute", maito ja tee.

V Tee, maito, "neilikkauute" ja vodka käsitellään kohdissa I, II, III ja IV annettujen ohjeiden mukaisesti. Teelusikallinen kuivattua hevosenlantaa kääritään tinapaperiin, jota kuumennetaan. Tämä 'hassis' hajoaa täten aivan hienoksi jauhoksi. Jauho ripotellaan lämpimän kupin pohjalle, jonka jälkeen lisätään vodka, "uute", maito ja tee.

VI Tee, maito, "neilikkauute", vodka ja hassis käsitellään kohdissa I, II, III, IV ja V neuvotulla tavalla. Käsimenetelmäisesti siitintä hankaamalla siitä valutetaan siemennestettä lämpimään kuppiin. Tämän jälkeen kuppia edelleen läm- 
mitetään, jotta siihen valutettu neste myös lämpenisi. Puikolla hämmentäen lisätään sen jälkeen 'hassis', vodka, "uute", maito ja tee. Juoma on sellaisenaan valmista nautittavaksi. (Numminen 1971, 30-31.)

Suorastaan orgastisen makuelämyksen ohjeistus sisältää itse asiassa kuusi eri reseptiä, joista kukin toistaa edellisen ja lisää yhden ainesosan. Jokainen resepti on edellistä moniaineksisempi ja voimakkaampi. Ohje sisältää ainesosia, joita ei yleensä käytetä kotikeittiöissä, ja huomio kiinnittyy kieliasuun, nimitysten liukuvuuteen. "Neilikkauute" toistuu aina lainausmerkeissä, kuivatusta hevosenlannasta tehty 'hassis' yksinkertaisissa lainausmerkeissä, jotka tosin katoavat välillä, ikään kuin ainesosat muuttuisivat toisiksi tai lannalla alun perinkin olisi tarkoitettu hassista. Resepti muistuttaa okkultistisia tai alkemistisia ohjeita, joissa maagisten periaatteiden mukaan käytettiin kehon eritteitä eri tarkoituksiin. Myös symbolisesti voimakkaasti latautunut siemenneste esiintyi antiikista uuden ajan alkuun asti viljellyissä ohjeissa, joiden tavoitteet vaihtelivat afrodisiakeista unilääkkeisiin ja metamorfooseihin. ${ }^{10}$

Tähän(kin) esoteeriseen tiedonalueeseen viitataan myös Lomonosovin moottorissa (2014, 41), josta löytyy Paracelsuksen ohje homonculusten kasvattamiseksi. Yllättäen siinäkin on kyse sperman ja hevosenlannan yhdistelmästä: "Miehen siemen täytyy asetella hermeettisesti sinetöityyn astiaan, joka haudataan hevosen lantaan 40 päiväksi. Lanta on tarpeen 'magnetisoida'”. Nummisen reseptin maaginen funktio jää arvailtavaksi, mutta jokainen osio lisää edellistä voimallisempia ja vaikuttavampia ainesosia. Neilikalla on uskottu olevan monia, mm. potenssia lisääviä ominaisuuksia, vodka juovuttaa, lanta lannoittaa, sperma hedelmöittää. Kallisarvoisen siemenen valuttaminen kuppiin viimeistelee mikstuuran, ikään kuin lataa sen voimalla.

Kari Aronpuron (s. 1940) pelkkää barnumia, yhdysvaltalaisen bisnesmiehen ja humpuukimaakarin P. T. Barnumin (1810-1891) hahmon ympärille temaattisesti kiertyvä konseptuaalinen runo- ja proosakokoelma (2014) sisältää myös ohjeet "fejeeruokiin", alaotsikolla "Etsitkö maistuvaa merenneitoreseptiä?"

Aikasen teuraan osien käytöstä

Selkäpaisti paistetaan uunissa.

Perä eli paisti paistetaan tuoreena uunissa.

Kotlettikappale käytetään kotletiksi.

Evälapa paistetaan uunissa tai käytetään lihapalleroiksi tai frikasseeksi.

Rinta keitetään frikasseeksi tai lihahyytelöksi. [- - ]

\section{Fejeemuhennos}

$1 \mathrm{~kg}$ zwergfejeetä

4 rlk voita

1 pieni rlkn täysi vehnäjauhoja

$1 "$ " suolaa $2 \mathrm{dl}$ vettä

1 rlk hienoksi leikeltyä sipuliruohoa

1 " " $"$ dilliä

" persiljaa 
Puhko ja huuhdo merenneitoset; lado ne rivittäin voin, jauhojen, suolan, dillin, persiljan ja sipuliruohon kanssa pieneen kastrulliin. Kaada kuumaa vettä päälle, pane kastrulli tulelle ja anna muhennoksen hiljaa muhia kannen alla pehmeäksi asti. Vie pöytään perunain kanssa. (Aronpuro 2014, 25.)

Tekstin kieliasusta voi päätellä, että se muun teoksen tavoin perustuu 1800-luvun teksteihin tai hyödyntää niitä. pelkkää barnumia on täynnä kopioituja, kierrätettyjä ja manipuloituja tekstiaineistoja. Merenneitoaihe tullee Barnumin huijauksesta, jossa maksavalle yleisölle esiteltiin Fijiltä ("Fejee") löytynyttä merenneitoa, joka todellisuudessa koostui kalan ruhoon ommellusta apinan päästä. Tekstin metodiikka tuntuu toistavan tällaista "koosteista", orgaanisen yhtenäisyyden rikkovaa copy-paste -periaatetta. Kaikki reseptit tietysti irrottavat ainesosansa luontoyhteydestään siirtäen ne uusiin yhdistelmiin. Merenneito on kulttuurinen ja kirjallinen hybridimuoto, jota emme ole tottuneet ajattelemaan ruhona tai "aikasena" teuraana. Teksti leikkii myös antikvaarisiin resepteihin kuuluvalla vanhahtavalla kieliasulla, jonka vieraus usein asettaa ne nykylukijan silmissä (ja suussa) huvittavan, vastenmielisen ja abjektiivisen rajapinnoille.

\section{Tekstin reseptit: ruuanlaitto ja kokeellinen kirjoittaminen}

Aki Salmelan (s. 1976) runo "Essentia Witae" (2005) yhdistää kolme toimintaa ohjaavaa kaavaa: reseptin, runomuodon (pantun, pantoum) sekä lähdetekstin käyttämisen (kopioinnin ja uudelleenjärjestelyn) kirjoittamisessa. Sen taustatekstinä ovat kansanlääkinnällisten ja maagisten lääke- ja juomaohjeiden kokoelma, K. Gananderin MaanMiehen Huone- ja Koti-Aptheeki (1788), ${ }^{11}$ tarkemmin sanottuna resepti nro 16 "Että tehdä Essentia Witae (Elämän öljyä.) ja mihenkä se kelpaa ja on hywä". Runo alkaa:

Ota lutrattua Salpietaria 3 luotia, Walkiata Wijnsteenia 3 luotia.

Uusi klaseerattu kruuku pannaan walkialle,

kuin se on tullut nijn läpi kuumaxi,

että yxi hypeellinen näistä sijhen nakattu syttyy ittestään

uusi klaseerattu kruuku pannaan walkialle.

Nijn pannaan Saltpietari ja Wijnsteeni sinne palamaan. että yxi hypeellinen näistä sijhen nakattu syttyy ittestään; hämmennetään nijnkauwwan kuin se palaa, rautaisella aseella.

Tämän jälkeen runo jatkuu vielä 6 säkeistöä samalla pantunin periaatteella, jossa edellisen säkeistön toinen ja neljäs säe toistuvat seuraavassa ensimmäisenä ja kolmantena. Lopussa mukaan tulee ensimmäisen säkeistön ensimmäisenä ja kolmantena olleet säkeet, jolloin runo ikään kuin sulkeutuu silmukaksi:

Asetetaan sitten Aurinkoon eli lämpymälle paikalle kakeluunille.

Ota lutrattua Salpietaria 3 luotia, Walkiata Wijnsteenia 3 luotia.

Nijn tulee se punasexi kuin weri, ja on walmis nautittaa,

kuin se on tullut nijn läpi kuumaxi. (Salmela 2005, 60.) 
Pantun, 1400-luvulla kehitetty, 1800-luvulla Eurooppaan tuotu ja myöhemmin esimerkiksi John Ashberyn (s. 1927) ja muiden kokeellisten nykyrunoilijoiden adoptoima toisteinen runokaava, niveltyy yhteen toisteisen reseptimuodon kanssa. Resepti sinällään on loputtomasti uusinnettava modus operandi, sitä määrittää myös loputon sisäinen variaatio, ja se on - ainakin tiettyyn rajaan asti - käyttäjän muokattavissa. Samat luonnehdinnat sopivat historiallisiin runomuotoihin ilmaisua ohjaavina pakotteina. Ei lienekään sattumaa, että kirjallisen luovuuden manipulaatioista ja kirjoittamisen pakotteista kiinnostunut ranskalainen kirjailijaryhmä OuLiPo (Ouvroir de Littérature Potentielle, "potentiaalisen kirjallisuuden työpaja") on sekä tuottanut ruoka-aiheisia tekstejä että laajentunut "potentiaalisen keittiön" haaraosastoksi (OuCuiPo, Ouvroir de Cuisine Potentielle). ${ }^{12}$ Kirjallisuuteen ja ruokaan (lukemiseen ja syömiseen) molempiin liittyy (hengen) ravinto, sulattaminen ja sisäistäminen (engl. digest), sekä tietysti kielenkäyttö. Valmistamisen näkökulmasta sekä teksti että ateria koostuvat valikoiden, työstäen ja kypsytellen koostetuista raaka-aineista, luovuuden ja kurinalaisuuden tasapainotellessa. Kirjoittamisen menetelmät tai kaavat ovat tekstin reseptejä.

Georges Perecin (1936-1982) "81 reseptiä aloittelijoille" yhdistää ruokaohjeisiin kuuluvan ainesten variaation OuLiPon keskeisiin ideoihin, permutaatioon ja lähdetekstimanipulaatioon. Oletettavasti Perecin lähtökohtana on ollut joku ranskalaisen keittokirjallisuuden klassikko, josta poimittujen kolmen pääraaka-aineen (kani, meriantura, kateenkorva) ja muutaman valmistustavan hellittämätön, toisteinen ja yhdistelevä permutaatio on monitulkintaista. Perecin reseptit jäävät häiritsevällä tavalla aidon ranskalaisen keittiön ja vastenmielisen vaikutelman välimaastoon. Onko jälkimmäinen haute cuisinen intentionaalista, permutoinnilla tuotettua parodiaa, vai pelkästään tutkijan subjektiivisen maun sanelema asia, jää avoimeksi. ${ }^{13}$ Pienimuotoisempaa mutta vielä ennakoimattomampaa ja selkeämmin humoristista ainesten rotaatiota edustaa Alastair Brotchien linssivanukas, johon tulee minttukeksejä, rusinoita, linssejä, kampasimpukoita, ananashyytelöä, kuivattua inkivääriä ja voileipäkeksejä (Mathews \& Brotchie 2005, 236). Tämä resepti ("always a favourite") on tehty Jean Lescuren sanakorvausmenetelmällä $S+7$, jossa lähdetekstin (satunnainen resepti) jokainen substantiivi korvataan systemaattisesti sanakirjassa, tässä tapauksessa Modern Cookery Illustrated -teoksen hakemistossa, seitsemäntenä siitä olevalla sanalla.

Harry Mathewsin "Maalaisresepti Keski-Ranskasta" on pituudessaan, monimutkaisuudessaan ja ainestensa vaivalloisessa alkuperäisyydessä koomisesti toteuttamiskelvoton resepti. Siinä voi halutessaan nähdä amerikkalaisen (mutta frankofiilin) kirjailijan huvittuneen näkökulman ranskalaiseen ruuanlaittoon - se on kuitenkin tällaista kulttuurista näkökulmaa moniulotteisempi teksti. Siinä vaihtelevat reseptimäinen imperatiivi, laveat kuvaukset ja muut poikkeamat. 
La Tour Lambertin hengästyttävän paksua kermaa säilytetään sille varta vasten kaivetuissa kellareissa. Ne, joilla ei sellaista ole, käyttävät kaupungin kylmäkellaria [- - . Olen usein katsellut kuinka asiasta vastaavat naiset menevät sisään ja tulevat ulos tuosta huoneesta, he ovat hämyisiä hahmoja huppuineen, šaaleineen ja pitkine harmaine kaapuineen, ja he kantavat savikannuja kuin uhrilahjoja pyhimyksille. (Mathews 2013, 66.)

Narratiivisuuden kannalta kiinnostavia ovat myös lukuisat ajalliset hyppäykset, jotka rikkovat tai monimutkaistavat reseptin ajallista proseduuria, jonka yleensä tulisi olla lineaarinen:

Sekoita kala ja neste tasaiseksi massaksi.

Kaksi tuntia aikaisemmin olet jäähdyttänyt $2 \frac{1}{2} 2$ desiä tukevinta saatavilla olevaa kermaa. Tämän suhteen lehmän omistaminen olisi tietysti siunaus. (Mathews 2013, 66.)

Tai:

Jonain aiempana tovina olet tehnyt täytteen kvenellejä varten. (Juuri tämä tekee täytteestä "kaksinkertaisen".) Se koostuu kalan maidista sekä lampaan kateenkorvasta ja haimasta. (Älä unohda sanoa niistä lihakauppiaalle.)

(Mathews 2013, 66.)

"Farce double", kaksinkertainen färssi eli mureke, tai farssi, viittaa myös tekstin kaksinkertaiseen rooliin, jossa se esittää itsensä ruokaohjeena, mutta on kuitenkin jotain muuta - koomiseen asetelmaan, joka määrittää kaikkia fiktiivisiksi resepteiksi nimittämiäni tekstejä.

Viimeinen esimerkkini, Harry Salmenniemen (s. 1983) novelli "Fantastinen salaatti" (2017) summaa useita edellä käsiteltyjä lähestymistapoja. Nykyisen ruokakulttuurin (jossa melkein jokainen kotikokki on vain aidoille asioille omistautunut asiantuntija) puhetapoihin kohdistuvan satiirin lisäksi sen tekotapa hyödyntää luettelointia, rajoitteita ja lähdeaineistoja. Kokoelman muista novelleista viisi käyttää nimettyjä lähdetekstejä, ja on todennäköistä että myös "Fantastisen salaatin" luettelot perustuvat johonkin tietokantaan. Novelli koostuu vuoropuhelusta, jossa salaatin valmistaja ja ihastuneet maistelijat ("Uskomatonta salaattia. Aivan mielettömän hyvää salaattia.") käyvät läpi salaatin ainesosat.

- Tässä taitaa olla myös kaalia.

- On siinä muutamiakin kaalilajikkeita. Siinä on ihan tavallista kiinankaalia, parsakaalia, kurttukaalia ja kukkakaalia, lehtikaalia, ruusukaalia ja kyssäkaalia. Lisäksi laitoin vastapainoksi joitakin harvinaisempia ja jännittävämpiä makuja, pinaattikiinankaalista välimerenkaaliin ja hoikkalitukaaliin. Toivottavasti monipuolisuuden huomaa. [- - ]

- Tässähän on vaikka mitä hedelmiä, eikö olekin?

- Valitsin joitakin lempihedelmiäni. [- -] Laitoin eniten ananasta, appelsiinia, aprikoosia, banaania ja keittobanaania, granaattiomenaa, kermaomenaa ja kiiviä. Mukana on myös ananaskirsikkaa, avokadoa, granadillaa, greippiä, 
guavaa, jakkihedelmää, kakia eli persimonia, kaktusviikunaa, karambolaa, kastanjaa, keltapassiota, kiwaita ja kiwanoa. (Salmenniemi 2017, 48-49.)

Jo lainauksesta huomaa, että kattaus on ensyklopedinen: se kulkee salaattikasveista, yrteistä, kaaleista, palkokasveista hedelmiin ja edelleen juustoihin ja riistaan. "Laitoin hieman pyytä ja riekkoa, samoin kiirunan rintapaloja, teertä ja metsoa." Huomio kiinnittyy paitsi kiivaaseen luettelointiin, joka on ristiriidassa emännän tai isännän vaatimattomuuden kanssa, myös ainesosien aakkosjärjestykseen, ikään kuin ruokaan liittyvä tieto olisi epäinhimillisellä tavalla sisäistettyä tai sulatettua. Samalla salaatin valmistaja toistelee ruokaharrastajien kliseisiä itsetehostuksia: "Yritin saada yrtit kaiuttamaan juustojen makuja"; "yritin keskittyä yksinkertaiseen riistaan"; "on minulla pimeä puolenikin, sillä jos maistelette tarkasti salaatissa on myös joitain englantilaisia juustoja”.

Ainesosien kirjaimellisesti fantastinen kumulaatio tuo mukaan myös abjektion mahdollisuuden. Ruuan valmistus perustuu rajaamiselle ja poisjättämiselle, ja salaatti, joka sisältää lähes kaiken, paitsi hylkää salaatin idean (valikointi) myös alkaa vaikuttaa "ei-ruualta", luotaantyöntävän maksimaaliselta koosteelta, vaikka ainesosat sinällään olisivat tavanomaisia. Kulttuuriset yhdistelmät ja koosteet (keittiössäkin) toimivat sen nojalla, mitä on jätetty pois. "Aluksi ajattelin laittaa myös karhunlihaa, mutta sitten se alkoi tuntua liioittelulta. Toivottavasti sen poissaoloa ei maista." Sekä "Maalaisresepti" että "Fantastinen salaatti" ovat absurdin liiallisia ruokia ja reseptejä, mutta niiden huumoria jäsentää myös kulinaarinen realismi, yhteys ruuan valmistukseen ja todellisiin ruokakulttuureihin.

\section{Annoksia kirjoittamassa - yhteenvetoja kirjallisista resepteistä}

Reseptit, joissa käytetään syömäkelvottomia (kiviä, lantaa, muovia) tai muuten inhottavia (kastematoja, kateenkorvaa, spermaa) ainesosia, ovat (tai voivat olla) huvittavia tiettyyn rajaan asti. Nauru voi olla reaktio inhon kokemukseen, syntyä älyllisestä havainnoinnista tai näiden (tosiaan seuraavasta) yhdistelmästä. Kristevaa seuraten voi ajatella, että ainoastaan symbolisesti merkittävät ja merkitsevät yhdistelmät voivat tuottaa vastenmielisyyden kokemuksen. Myös sinänsä kelvollisten ainesten poikkeavat yhdistelmät voivat herättää huvittuneisuuden lisäksi inhoa. Tällainen vaikuttavien yhdistelmien periaate muistuttaa surrealismin estetiikkaa. ${ }^{14}$

Kirjallisia reseptejä ja annoksia voi tarkastella tällaisten affekteihin liittyvien seikkojen lisäksi myös rakenteellisesta ja proseduraalisesta näkökulmasta. Resepti on aina käyttäjänsä ohjelmoiva koodi, avoin skripti, ja yhdellä reseptillä on tuottava suhde ärettömään määrään mahdollisia annoksia. Jokaisen reseptin toteuttaminen on tässä mielessä kokeellinen tilanne. Esittelemistäni teksteistä voi päätellä, että kirjailijat ovat olleet tietoisia ja kiinnostuneita juuri resepteihin kuuluvista rakenteellisista ja proseduraalisista piirteistä: luetteloinnista, toistosta, avoimuudesta, rajoitteista, variaatiosta, 
kierrätyksestä, permutaatiosta, operatiivisista paradokseista. Viimeksi mainittua edustaa myös Metsäroiston ohje sianpääsyltyn valmistamiseksi, joka vitsin varjolla tuo esille sen etäisyyden, joka on aina reseptin, kokin ja annoksen välissä.

Sianpääsyltty rommikastikkeella

Valmistetaan sianpääsyltty ja ranskalainen rommikastike. Syödään keitettyjen perunoiden kanssa. (Seilonen 1986, 78.)

Kirjallinen resepti pelaa aina kaksoisstandardilla, jonka jälkiä lukija voi löytää teksteistä. Mathewsin ja Salmenniemen mahdottomat reseptit ovat myös viittauksia kirjoittamista jäsentävään luovuuteen: "Älä välitä, jos itse olet menettänyt kaiken halusi syödä. [- -] Sinun tyydytyksesi on tekemisessä, ei tehdyssä.” (Mathews 2013, 71.) Kaksoisstandardin toinen puoli, se mitä on reseptin takana, on sisällöllis-käsitteellinen yllyke, joka jää lukijan maisteltavaksi ja sulatettavaksi. ”Minä tein kastikkeen itse alusta loppuun, mutta sen reseptiä en paljasta. Se on paljon salaattia yksinkertaisempi." (Salmenniemi $2017,52.)^{15}$

\section{Viitteet}

${ }^{1}$ Ruokatematiikkaa käsittelevästä kirjallisuudentutkimuksesta ks. esim. Adamson 1995; Kainulainen \& Parente-Čapková 2006; Joensuu 2015; Koistinen 2004; Leonardi 1989. Yleisemmästä ruokakulttuurisesta kontekstista ks. esim. Hämeen-Anttila \& Rossi 2015; Knuuttila 2010, Worth 2015.

${ }^{2}$ Richardsonin $(1991,310)$ kolme toisen persoonan kerronnan tyyppiä: tavanomainen (standard), subjunktiivinen (subjunctive) ja autotelinen (autotelic).

3 "First and third person novels have obvious non-fictional counterparts in autobiography and biography, but second person is an exclusively and distinctively literary phenomenon, its only non-fictional analogues being the pseudo-narrative forms of the cook book, the travel guide, and the self-help manual."

${ }^{4}$ Tarkemmin: Joensuu 2015, 233.

${ }^{5}$ Humoristiset ihmislihareseptit eivät ole välttämättä satiirisia, kuten muistetaan TV1:n Velipuolikuun (1983-1984) pääsiäishanukkaasta: ”Tällä kertaa valmistamme muinaissuomalaisen ruokaperinteen mukaista pääsiäishanukasta. Tarveaineet neljän hengen annokseen ovat: 1 raaka hanu; 20 litraa voitaikinaa; $8 \mathrm{dl}$ voisulaa; 1 omena. Raaka hanu nostetaan taikinapedille ja asetellaan sikiöasentoon. [jne.] Paistuakseen vaatii tällainen 80 kg:n hanu 250 astetta, jolloin paistoaika on kuutisen tuntia." (Kyrönseppä 2014, 95-96, sketsin kirjoittanut Kari Heiskanen.) Myös Juha Ruusuvuori harjoitti antropofagiaa pilaillessaan Pahkasiassa 1/1986 perinneruuilla ja maakuntastereotypioilla: "Jepualta on kotoisin Pohjanmaan makoisa perinnepöperö, veritorttu [- -]. Tätä ruokaa varten tarvitaan kuusi litraa vastalaskettua verta. [- - 1930-luvulla verta laskettiin etupäässä työväentalojen vahtimestareista, joilla oli eteläpohjalaisten tiedemiesten mukaan korkea veriarvo."

(Ruusuvuori 1986, 14-15.)

${ }^{6}$ Tarkemmin: Joensuu 2015, 233-234. 
7 "Food becomes abject only if it is a border between two distinct entities or territories." Kristeva 1982, 75.

${ }^{8}$ Naurua ja abjektiota yhdistää se, että molemmat ovat subjektiivisia reaktioita "objektiivisiin” asioihin. Esimerkiksi Kristeva (1982, 2-3) käyttää triviaalia (siis subjektiivista) esimerkkiä hyvin voimakkaan abjektion synnystä: lämpimän maidon pintaan syntyvää kuorta.

${ }^{9}$ Toisin kuin 80-luvun Suomessa, nykyään raaka kala (sushi) on suosittu lounasruoka ja hyönteisravinto nouseva trendi. Kirjalliset reseptit voivat myös luoda tosimaailman trendejä, kuten kävi Veikko Huovisen novellissa "Juopottelijan etiikka” (1969) keksimälle salmiakkikossulle.

${ }^{10}$ Kuten italialaisessa käsikirjoituksessa 1400-luvulta: "Rakkauteen ihmeellinen eksperimentti reseptin muodossa. Ota karvoja kainalosta, kädestä, reidestä, jaloista ja kiveksistä ja niistä osista, jotka ovat lähempänä elintä, sekä myös takamuksesta aukon ympäriltä. Ja ota kangasta [- - [jossa on] omaa spermaasi. Polta nämä kaikki, jauha pulveriksi ja anna siitä hieman syötäväksi haluamallesi naiselle, ja tämä tulee roihuamaan rakkaudesta sinua kohtaan [- - ].” (Boudet 2006, 422. Suom. Lauri Ockenström.) Karvojen syömisen voimaan on uskottu myös suomalaisessa kansantaikuudessa. ”Kylmenevää rakkautta voidaan kiihoittaa ottamalla 'rakkaudesta palavan' ihosta karvoja, leikkaamalla ne hienoksi ja antamalla kylmäsydämisen nauttia viinan kanssa. Erittäinkin näyttävät eräiden ruumiinosien karvat, kuten pudenda- ja kainalokuoppakarvat, olleen käytettyjä lemmenjuomissa." (Hämäläinen 1920, II luku). ${ }^{11}$ http://ekirjasto.kirjastot.fi/sivustot/maan-miehen-huone-ja-koti-aptheeki (27.3.2017). ${ }^{12}$ OuCuiPosta ks. Mathews \& Brotchie 2005, 325-326.

${ }^{13}$ Alison James $(2009,197)$ laskee reseptin Perecin humorististen tekstien joukkoon, jotka parodioivat permutaatiolla tiettyjä arkipäiväisen kirjoituksen muotoja.

${ }^{14}$ Dalín reseptikokoelma (2016/1973) lienee huomattavin surrealistinen keittokirja. Kurt Schwittersin ja Raoul Hausmannin yhteisteos Pin (1962) sisältää surrealistisia menyitä. Futuristien keittiöstä ks. Marinetti \& Filia 2015.

${ }^{15}$ Artikkeli on kirjoitettu osana Suomen Akatemian rahoittamaa The Literary in Life: Exploring the Boundaries between Literature and the Everyday -konsortiohanketta (hanke numero 285144). Kiitokset magian historiaan liittyvistä vinkeistä: FT Lauri Ockenström ja kirjailija Jaakko Yli-Juonikas.

\section{Kirjallisuus}

Adamson, Melitta Weiss 1995. The Games Cooks Play: Non-Sense Recipes and Practical Jokes in Medieval Literature. Food in the Middle Ages: A Book of Essays. New York: Garland.

Aronpuro, Kari 2014. Fejeeruokia. pelkkää barnumia. cargo. Helsinki: ntamo.

Boudet, J. 2006. Entre science et nigromance: Astrologie, divination et magie dans l'occident médiéval (XIIe-XVe siècle). Paris: Publications de la Sorbonne.

Brillat-Savarin, Anthelme 1988. Maun fysiologia. (Physiologie du goût, 1826.) Suom. Jukka Mannerkorpi. Jyväskylä \& Helsinki: Gummerus.

Dalí, Salvador 2016/1973. Les Dîners de Gala. Taschen. 
Goody, Jack 1995/1977. The Domestication of the Savage Mind. Cambridge: Cambridge UP.

Edson, Russell 2011. Intuitiivinen matka. Valitut runot. Suom. Aki Salmela. Turku: Savukeidas.

Herman, David 1997. Scripts, Sequences, and Stories: Elements of a Postclassical Narratology. PMLA. Publications of the Modern Language Association of America Oct 1997; 112, 5; 1046-1059.

Huovinen, Veikko 2012/1959. Uusia ruokia. Luonnonkierto. Novelleja, pakinoita, lyhyitä erikoisia 1950-2001. Helsinki: Siltala.

Huovinen, Veikko 1990/1967. Parempi kohtelu keskitysleireille. Lyhyet erikoiset. Helsinki: WSOY.

Huovinen, Veikko 1986. Stalinin syntymäpäivän vietto keskitysleirillä. Matikanopettaja. Helsinki: Otava.

Huovinen, Veikko 1973. Ihmissyöntiä I - II: Rasvamaksa \& Pystyyn marinoitu nainen. Rasvamaksa. Helsinki: Suuri Suomalainen Kirjakerho.

Hämeen-Anttila, Jaakko \& Venla Rossi 2015. Nälästä nautintoihin. Ruoan tarina. Helsinki: Otava.

Hämäläinen, Albert 1920. Ihmisruumiin substanssi suomalais-ugrilaisten kansojen taikuudessa. Taikapsykologinen tutkimus. Suomalais-ugrilainen Seura. Project Gutenbergin sähkökirjan tuottaneet Sarianna Tamminen and Tapio Riikonen. http://www.gutenberg.org/ebooks/48595

James, Alison 2009. Constraining Chance. Georges Perec and the Oulipo. Evanston, Illinois: Northwestern UP.

Joensuu, Juri 2015. Naukkuja, zakuskoita, juhla-aterioita. Veikko Huovisen koominen hillintä. Pekka Hakamies, Seppo Knuuttila \& Elina Lampela (toim.), Huumorin skaalat. Esitys, tyyli, tarkoitus. Kalevalaseuran vuosikirja 94. Helsinki: SKS, 230-245.

Kainulainen, Siru \& Viola Parente-Čapková (toim.) 2006. Täysi kattaus. Ruokaa ja juomaa kirjallisuudessa. Turku: Turun yliopiston Taiteiden tutkimuksen laitos.

Kirstinä, Väinö 1965. Luonnollinen tanssi. Helsinki: Tammi.

Kivi, Aleksis 2012/1873. Seitsemän veljestä. Helsinki: SKS.

Kivistö, Sari \& H. K. Riikonen 2012. Satiiri Suomessa. Helsinki: SKS.

Knuuttila, Maarit 2010. Kauha ja kynä. Keittokirjojen kulttuurihistoriaa. Helsinki: SKS.

Koistinen, Tero 2004. ”Hyvälle maistui Pörhösen maksa." Ruokakulttuurien kohtaamisia Veikko Huovisen tuotannossa. Maarit Knuuttila, Jyrki Pöysä ja Tuija Saarinen (toim.), Suulla ja kielellä. Tulkintoja ruuasta. Tietolipas 202. Helsinki: SKS, 256-270. 
Kristeva, Julia 1982. Powers of Horror. An Essay on Abjection. Transl. by Leon S. Roudiez. New York: Columbia UP.

Kyrönseppä, Kari 2014. Velipuolikuun vetovoima. Pääsiäishanukkaan valmistus ja muita sketsiohjeita. Jyväskylä: Docendo.

Leonardi, Susan J. 1989. Recipes for Reading: Summer Pasta, Lobster à la Riseholme, and Key Lime Pie. PMLA: Publications of the Modern Language Association of America 104.3 (1989 May), 340-347.

Lähde, Kristiina, Aki Salmela, Saila Susiluoto \& Tuomas Timonen 2004. Reseptejä. Nuori Voima 4-5/2004.

Marinetti, F.T. \& Filia 2015. Futuristinen keittiö. Ruokakulttuuria ja reseptejä. Esipuhe Marja Härmänmaa, suom. Pauliina de Anna. Turku-Tampere-Tallinna: Savukeidas.

Mathews, Harry 2013. Maalaisresepti Keski-Ranskasta: Paahdettu luuton ja sidottu täytetty lampaanselkä (farce double). (Country Cooking from Central France: Roast Boned Rolled Stuffed Shoulder of Lamb (Farce double), 1978). Suom. Aki Salmela. Nuori Voima 4/2013.

Mathews, Harry \& Alastair Brotchie 2005. Oulipo Compendium. Revised \& Updated. London: Atlas Press, Los Angeles: Make Now Press.

Nabokov, Vladimir 1999. Nabokoviksi keitetyt kananmunat. (Vladimir Nabokov’s Eggs à la Nabocoque, 1972). Suom. Kaisa Sivenius. Nuori Voima 6/1999.

Numminen, M. A. 1971. Teen todellinen maku. Lastuja. Helsinki: Karisto.

Perec, Georges 2004. 81 reseptiä aloittelijoille. (81 fiches-cuisine à l'usage des débutants, 1980.) Suom. Mirja Halonen. Nuori Voima 4-5/2004.

Rabelais, François 2014. Pantagruelin neljäs kirja. (Le quart livre des faicts et dits hérö̈ques du bon Pantagruel, 1552.) Suom. Ville Keynäs. Helsinki: Siltala.

Richardson, Brian 1991. The Poetics and Politics of Second Person Narrative. Genre XXIV (Fall, 1991), 309-330.

Ruusuvuori, Juha 1986. Maakuntien perinneruuat nuijittu pöytään Suomessa. Pahkasika 1/1986, 14-16.

Ruusuvuori, Juha 1991. Lama-ajan keittokirja. Pahkasika 4/1991, 56-58.

Salmela, Aki 2005. Essentia witae. Pantun. Tuli \& Savu 3/2005, 60.

Salmela, Aki 2011. Mies joka kirjoittaa - lyhyt johdanto Russell Edsonin runouteen. Russell Edson: Intuitiivinen matka. Valitut runot. Suom. Aki Salmela. Turku: Savukeidas.

Salmenniemi, Harry 2017. Fantastinen salaatti. Uraanilamppu ja muita novelleja. Helsinki: Siltala.

Salminen, Antti 2014. Lomonosovin moottori. Helsinki: Poesia.

Seilonen, Kalevi 1986. Metsäroisto. Helsinki: Tammi. 
Swift, Jonathan 1998. Vaatimaton ehdotus. (A Modest Proposal For preventing the Children of Poor People From being a Burthen to Their Parents or Country, and For making them Beneficial to the Publick, 1729.) Irlantilaisia pamfletteja. Toim. ja suom. Jyrki Vainonen. Helsinki: Loki-Kirjat.

Tokarczuk, Olga 2004. Päivän talo, yön talo. (Dom dzienny, dom nocny, 1998.) Suom. Tapani Kärkkäinen. Helsinki: Otava.

Worth, Susannah 2015. Digesting Recipes. The Art of Culinary Notation. Alresford: Zero Books. 